\title{
Ammonia volatilization losses in Tanzania grass fertilized with urea
}

\author{
Perdas de amônia por volatilização em capim-Tanzânia adubada com ureia
}

\author{
SOARES FILHO, Cecílio Viega ${ }^{*}$; CECATO, Ulysses ${ }^{2}$; RIBEIRO, Ossival Lolato ${ }^{3}$; \\ ROMA, Cláudio Fabrício da Cruz ${ }^{4}$; BELONI, Tatiane ${ }^{4}$
}

\author{
${ }^{1}$ Universidade Estadual Paulista Júlio de Mesquita Filho, Faculdade de Medicina Veterinária, \\ Departamento de Apoio, Produção e Saúde Animal, Araçatuba, São Paulo, Brasil. \\ ${ }^{2}$ Universidade Estadual de Maringá, Departamento de Zootecnia, Maringá, Paraná, Brasil. \\ ${ }^{3}$ Universidade Federal da Bahia, Escola de Medicina Veterinária e Zootecnia, Departamento de Zootecnia, \\ Salvador, Bahia, Brasil. \\ ${ }^{4}$ Universidade Estadual de Maringá, Maringá, Paraná, Brasil. \\ *Endereço para correspondência: cecilio@ fmva.unesp.br
}

\section{SUMMARY}

Gaseous losses are the main factors affecting the efficiency of nitrogenous fertilizers in pastures. To evaluate $\mathrm{NH}_{3}-\mathrm{N}$ volatilization losses in Tanzania grass fertilized with urea in autumn, spring and summer, a completely randomized design with repeated measurements over time and fifteen replicates was used. Plots were represented by urea levels $(50 ; 100$ and $150 \mathrm{~kg}$ $\left.\mathrm{ha}^{-1} \mathrm{~N}\right)$ and subplots by time after fertilization $(1 ; 2 ; 3 ; 6 ; 9 ; 12$ and 15 days). The interaction between fertilization leveland time after urea application was significant for the accumulated $\mathrm{NH}_{3}-\mathrm{N}$ volatilization. Urea application leads to higher percentage $\mathrm{N}$ losses in the first three days after application. The average cumulative $\mathrm{NH}_{3}$ $\mathrm{N}$ loss for the three occasions (different seasons of the year) was $28 \%, 20 \%$ and $16 \%$ of $\mathrm{N}$ applied for fertilizer doses of 50; 100 and 150 $\mathrm{kg} \mathrm{ha}^{-1}$ of $\mathrm{N}$, respectively. The season of the year influenced $\mathrm{NH}_{3}-\mathrm{N}$ loss pattern and volume, with the lowest values recorded in spring, followed by summer and autumn. The cumulative $\mathrm{NH}_{3}-\mathrm{N}$ volatilization loss varies from 78 to $90 \%$ up to the third day after application of the total $\mathrm{N}$ $\mathrm{NH}_{3}$ loss.

Keywords: Panicum maximum, nitrogen fertilizer, pasture

\section{RESUMO}

As perdas gasosas são os principais fatores de ineficiência do uso de fertilizantes nitrogenados nas pastagens. Com o objetivo de estimar a perda $\mathrm{N}-\mathrm{NH}_{3}$ por volatilização foi realizado um experimento com capim Tanzânia adubada com ureia nas estações de outono, primavera e verão. Adotou-se um delineamento experimental inteiramente casualizado, com medidas repetidas no tempo com quinze repetições. Nas parcelas, as doses de $\mathrm{N}$-ureia $(50,100$ e $150 \mathrm{~kg}$ ha $^{-1}$ de N-ureia) e, nas subparcelas, o período depois da adubação nitrogenada $(1,2,3,6,9,12$ e 15 dias). A interação entre o nível de adubação e o período depois da aplicação de ureia foi significativa para a variável volatilização acumulada de $\mathrm{N}_{-} \mathrm{NH}_{3}$. A aplicação da ureia acarreta perdas percentuais mais elevadas de $\mathrm{N}$ nos três primeiros dias após a aplicação. A perda média acumulada de $\mathrm{N}-\mathrm{NH}_{3}$ no período para as três estações do ano representou $28 \%, 20 \%$ e $16 \%$ do $\mathrm{N}$ aplicado nas adubações com 50, 100 e $150 \mathrm{~kg} \mathrm{ha}^{-1}$ de $\mathrm{N}$-ureia, respectivamente. A estação do ano influenciou no padrão e na quantidade das perdas, com menores valores encontrados na primavera, seguidos do verão e outono. A perda acumulada de $\mathrm{N}-\mathrm{NH}_{3}$ por volatilização variou de 78 a $90 \%$ até o terceiro dia após aplicação do total perdido.

Palavras-chave: Panicum maximum, fertilizante nitrogenado, pastagem 


\section{INTRODUCTION}

Nitrogen fertilization has been widely used on grass pastures to increase pasture growth and animal production. Urea is a very popular fertilizer due to its high $\mathrm{N}$ content, easy handling and moderate acidifying effect.

However, nitrogen losses from applying urea as $\mathrm{N}$ source can be considerable. Applying urea to the soil in the presence of water and urease leads to hydrolytic generation of ammonia $\left(\mathrm{NH}_{3}\right)$, carbon dioxide $\left(\mathrm{CO}_{2}\right)$ and water (SENGIK \& KIEHL, 1995).

Ammonia may be lost or retained by the system depending on environmental conditions. Under unsuitable conditions for ammonia retention by the soil, volatilization may cause large losses. In pastures where large quantities of urea are applied directly to the soil surface, a decrease in the cation exchange capacity and increasein ammonia saturation (KIEHL, 1989) are observed, favoring $\mathrm{N}$ losses due to volatilization.

Therefore, in economic terms, urea can be considered a potentially high-quality fertilizer due to its high $\mathrm{N}$ content, easy handling and moderate acidifying effect. This justifies further efficiency investigation particularly regarding intensive exploitation pastures.

The volatilization process has received great attention in recent years due to its contribution to the deterioration of air quality and economic losses caused by the low efficiency of applied fertilizers (PRIMAVESI et al., 2004), being defined as the transfer of gaseous ammonia from soil to the atmosphere, requiring the presence of ammonia close to the soil surface, where ammonium ion $\left(\mathrm{NH}_{4}{ }^{+}\right)$, precursor of ammonia, is constantly formed in the soil by mineralization of organic matter by the decomposition of animal and plant waste and by the hydrolysis of amide and ammonium fertilizers.

This work aimed to quantify $\mathrm{NH}_{3}-\mathrm{N}$ volatilization losses in Tanzania grass pastures fertilized with urea in spring, summer and fall.

\section{MATERIAL AND METHODS}

The experiment was carried out in a Panicum maximum cv. Tanzania pasture on an experimental area belonging tothe Iguatemi Experimental Farm, Maringá State University, Maringá, state of Paraná, Brazil, $\left(23^{\circ} 25^{\prime} \mathrm{S}\right.$; 51 ${ }^{\circ} 57^{\prime} \mathrm{W}$ and $550 \mathrm{~m}$ a.s.1.). According to Corrêa (1996) and the Köppen classification, the local climate is Cfa subtropical humid mesothermal with hot summers, and summer-dominant rainfall. Weather data for the experimental period were collected at a meteorological station and are shown in Figure 1.

The soil type at the experimental area is dystrophic red latosoil (Santos et al., 2006) with the following chemical characteristics: $\mathrm{pH} \mathrm{CaCl}_{2}$ : 4.8; $\mathrm{P}$ (ionexchange resin extraction method) $=9.0$ $\mathrm{mg} \mathrm{dm}{ }^{-3}$; organic carbon $=12.7 \mathrm{~g} \mathrm{dm}^{-3}$; $\mathrm{Ca}=1.0 \mathrm{cmol}_{\mathrm{C}} \mathrm{dm}^{-3} ; \mathrm{Mg}=0.7 \mathrm{cmol}_{\mathrm{c}} \mathrm{dm}^{-3}$; $\mathrm{K}=0.09 \mathrm{cmol}_{\mathrm{c}} \mathrm{dm}^{-3}$; cation exchange capacity $=4.8 \mathrm{cmol}_{\mathrm{c}} \mathrm{dm}^{-3}$ and base saturation $=38.6 \%$. At the beginning of the experimental period, the soil was corrected with $40 \mathrm{~kg} \mathrm{ha}^{-1}$ of $\mathrm{P}_{2} \mathrm{O}_{5}$ as simple superphosphate $\left(18 \%\right.$ of $\left.\mathrm{P}_{2} \mathrm{O}_{5}\right)$. Acidity correction was performed with dolomitic limestone in order to increase base saturation to $60 \%$ according to Werner et al. (1996). Nitrogen (as urea, 46\% N) was applied in fall (April 18, 2007), spring (November 12, 2007) and summer (January 24, 2008) by sprinkling over the plots early in the morning on the day after all animals were removed from the fenced area. Together with the first $\mathrm{N}$ application, $60 \mathrm{~kg} \mathrm{ha}^{-1} \mathrm{~K}_{2} \mathrm{O}$ were applied as potassium chloride $\left(60 \% \mathrm{~K}_{2} \mathrm{O}\right)$. 
Rev. Bras. Saúde Prod. Anim., Salvador, v.16, n.1, p.253-264 jan./mar., 2015 http://www.rbspa.ufba.br ISSN 15199940

a

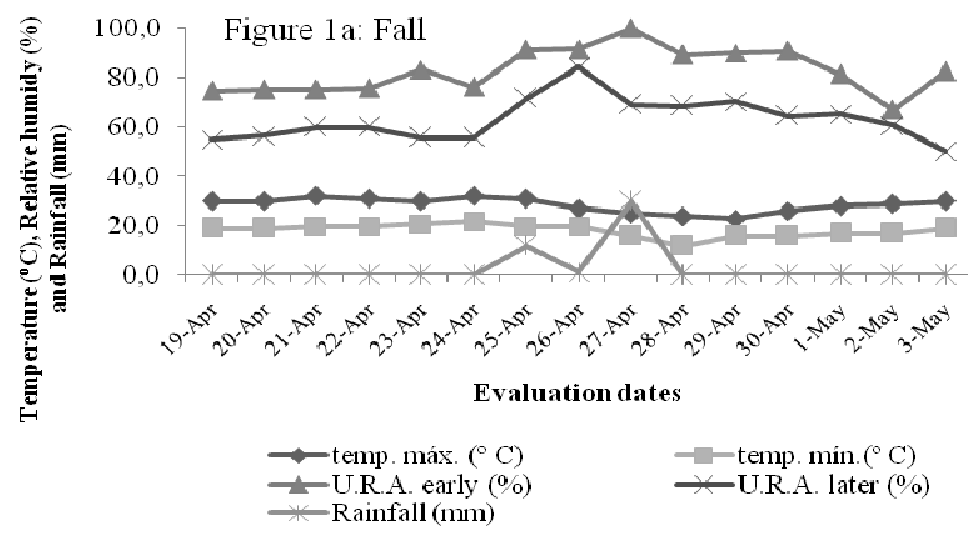

$\mathrm{b}$

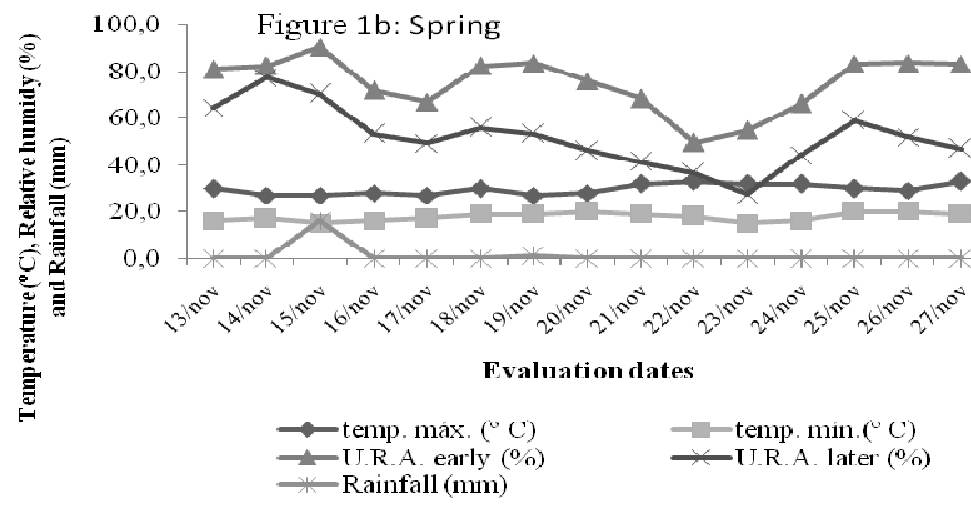

c

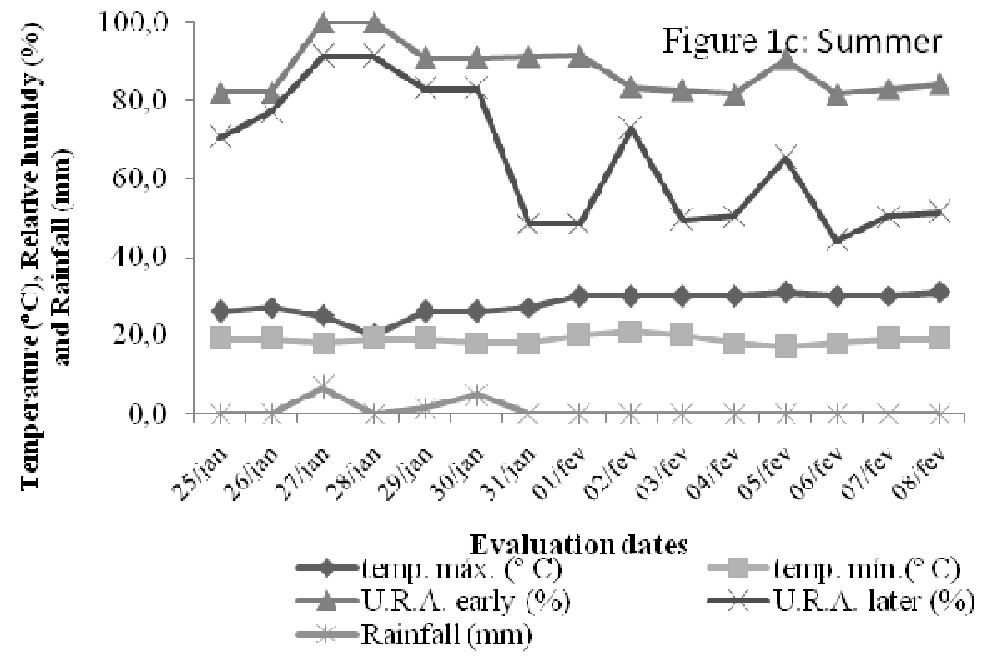

Figure 1. Means of daily highest and lowest air temperatures $\left({ }^{\circ} \mathrm{C}\right)$, relative air humidity in the morning and afternoon (\%) and rainfall $\left(\mathrm{mm} \cdot \mathrm{day}^{-1}\right)$ during the collection period in (southern hemisphere) fall (a), spring (b) and summer (c) from April 2007 to February 2008. Source: Iguatemi Experimental Farm Meteorological Station 
The pattern and extent of $\mathrm{N}-\mathrm{NH} 3$ volatilization were evaluated in noncultivated parcels with collectors randomly distributed over a $100 \mathrm{~m}^{2}$ area. The non-cultivated areas were the soil surface not occupied by the basal area of clumps. At the beginning of the experiment, on the day following removal of animals from the area, the height of the post-grazing residue was about $30 \mathrm{~cm}$.

The experimental design was fully randomized with measurements repeated over time with 15 replicates. The plots were the urea doses $(50 ; 100$ and $150 \mathrm{~kg}$ $\mathrm{ha}^{-1}$ of $\mathrm{N}$ ) and subplots were time after nitrogen fertilization $(1 ; 2 ; 3 ; 6 ; 9 ; 12$ and 15 days). Control treatment (zerokg ha ${ }^{-1}$ of $\mathrm{N}$ ) was considered a bank (i.e., $\mathrm{N}-\mathrm{NH} 3$ losses occurring without the influence of nitrogen fertilization) and used to correct $\mathrm{N}-\mathrm{NH} 3$ losses in fertilizations with 50 , 100 and $150 \mathrm{~kg} \mathrm{ha}^{-1}$ of $\mathrm{N}$. The application of treatment was analyzed from material collected in fall (April 19 to May 3, 2007), spring (November 13 to November 27, 2007) and summer (January 25 to February 8, 2008).

Semi-open static collectors were made of 2L PET transparent plastic bottles (0.35 $\mathrm{m}$ high, $0.10 \mathrm{~m}$ diameter) according to Marsolla and Miyazawa (1999), which were kept at $0.05 \mathrm{~m}$ from the soil surface by a wooden stake so that air could circulate inside simulated naturalfield conditions. Three collectors hung from each wooden stake making 15 collectors (replicates) were used per treatment. A paper filter ribbon $0.025 \mathrm{~m}$ wide and 0.25 $\mathrm{m}$ long was fixedinside the collector with a stainless steel wire. The ribbon was kept in contact with a collecting pad soaked in $0.05 \mathrm{~mol} / \mathrm{LH}_{2} \mathrm{SO}_{4}+2 \%(\mathrm{v} / \mathrm{v})$ glycerol collection solution in a $15 \mathrm{ml}$ graduated tube for $\mathrm{N}-\mathrm{NH} 3$ absorption. Paper filter ribbons and the sulphuric acid solution were replaced for each new sampling according to procedures previously described. Samples were kept in plastic bags with clear content identification and stored under refrigeration until analysis.

Aggregate ammonia losses due to volatilization (given in $\%$ and $\mathrm{kg} \mathrm{ha}^{-1}$ of $\mathrm{N})$ were computed from measurements performed on days $1,1+2,1+2+3$, $1+2+3+6, \quad 1+2+3+6+9, \quad 1+2+3+6+9+12$ and $1+2+3+6+9+12+15$.

Data were tested for error normality and variance homogeneity. Statistical analysis was carried out with the help of the SAS statistical package (STATISTICAL ANALYSIS SYSTEM, 1999) version 8.2 for Windows. The GLM procedure was used for the split-subplot model, and $\mathrm{N}$ doses were considered as the main treatment and the collection period as the subplot. A separate analysis was performed for each season in the study (fall, spring and summer). The means were compared by the F-test and SNK means testedat 5\% significance level. Regression analyses were carried out as a function of $\mathrm{N}$ doseand multiple regression model adjustment (response surface) as a function of $\mathrm{N}$ doseand days after $\mathrm{N}$ application.

\section{RESULTS AND DISCUSSION}

Absolute $\mathrm{NH}_{3}-\mathrm{N}$ volatilization losses during fall 2007 were significant for the urea application rate, number of days after application and interaction between urea dose and number of days after application (Figure 3a). $\mathrm{NH}_{3}-\mathrm{N}$ volatilization losseswere higher for 100 and $150 \mathrm{~kg} \mathrm{ha}^{-1} \mathrm{~N}$ than for $50 \mathrm{~kg} \mathrm{ha}^{-1}$ in fall and summer but in spring, losses were higher at $150 \mathrm{~kg} \mathrm{ha}^{-1}$ than at 50 or $100 \mathrm{~kg} \mathrm{ha}^{-1}$. Season also affected the loss rate, with maximum losses occurring after about 3 days in summer, 6 days in spring and 9 days in fall (Figure 2). It was observed that on the days following 
Rev. Bras. Saúde Prod. Anim., Salvador, v.16, n.1, p.253-264 jan./mar., 2015 http://www.rbspa.ufba.br ISSN 15199940

$\mathrm{N}$ fertilization, losses were higher as a consequence of the greater volume of $\mathrm{N}$ on the pasture soil and also to the weather conditions (MARTHA JUNIOR et al., 2004). As observed in Figure 2a, $78 \%$ of the total aggregate loss computed for the entire experimental period was lost up to the $6^{\text {th }}$ day after application. The high temperatures on the first three days resulted in $12.8 \mathrm{~mm}$ rainfall three days before and $11.8 \mathrm{~mm}$ rainfall on the $7^{\text {th }}$ day after urea application (Figure 1). This must have contributed to the greater $\mathrm{N}-\mathrm{NH} 3$ loss observed in that period.
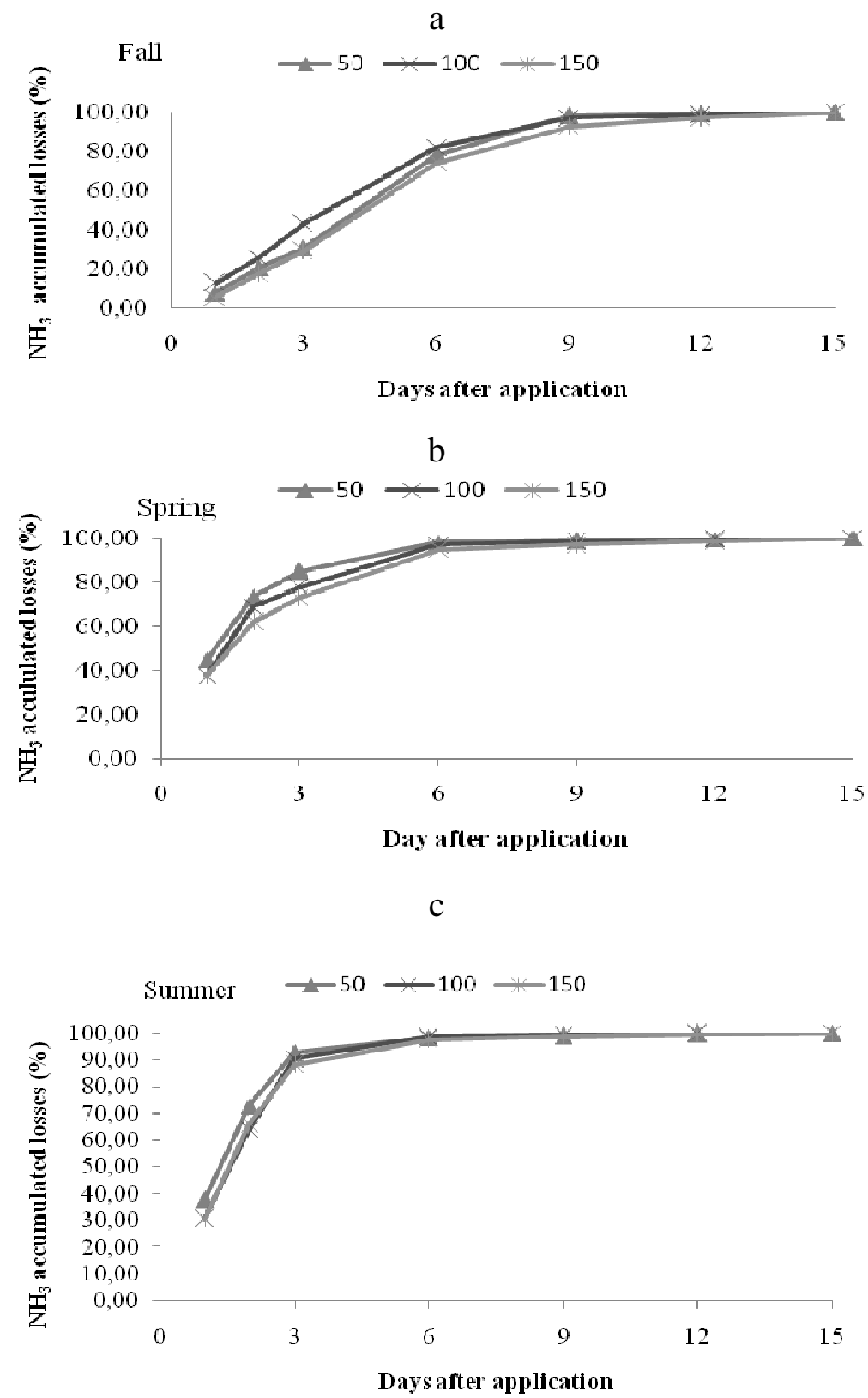

Figure 2. Accumulated $\mathrm{NH}_{3}-\mathrm{N}$ volatilization losses in Tanzania grass pastures fertilizedwith urea levels in fall (a), spring (b) and summer (c) from April 2007 to February 2008 
These results corroborate those of Martha Junior et al. (2004) who studied Tanzania grass fertilized with $\mathrm{N}$-urea and found on the third day, aggregate losses from 78 to $92 \%$ of the total $\mathrm{N}$ $\mathrm{NH} 3$ loss. Cantarela et al. (2008) found $\mathrm{NH}_{3}-\mathrm{N}$ volatilization losses as ammonia from urea treatments ranging from $1 \%$ (rainy days after fertilization) to $25 \%$ of the $\mathrm{N}$ applied in sugarcane. Lara \& Trivelin (1990) found similar results, where the first six days accounted for nearly $95 \%$ of the total $\mathrm{N}-\mathrm{NH} 3$ volume absorbed by the collector. Since the water volume was not enough to cause fertilizer infiltration into the soilprofile, ammonia must have remained concentrated on its surface, increasing the probability of loss.

In the present study, losses were similar to those found in literature. However, the pasture was covered with a significant volume of litter, which must have contributed for the retention of humidity on the soil surface soon after urea application on spaces among Tanzania grass shrubs. In turn, such humidity retention may have caused urease enzyme synthetization by soil microorganisms, which intensified urea hydrolysis and favored volatilization losses. Studies have shown that N-based fertilizers should be applied in a volume $30 \%$ larger when sowing directly over grass in order to compensate nitrogen retention by the grass above the ground. From the $9^{\text {th }}$ to the $15^{\text {th }}$ day, the mean aggregate $\mathrm{N}-\mathrm{NH}_{3}$ loss decreased as a fraction of the total loss with respect to the amount of fertilizer applied to the soil, indicating that $\mathrm{N}$ transfer from the fertilizer to the lower soil layers favored the ion-root contact with a better use of the fertilizer by the plant or $\mathrm{N}$ immobilization by microorganisms, as well as adsorption of $\mathrm{N}^{-\mathrm{NH}_{4}}{ }^{+}$forms potentially convertible into $\mathrm{NH}_{3}$ in the negative charges of soil particles, with a negative effect on the volatilization process (HARGROVE et al., 1988).

According to Figure 3a, aggregate N$\mathrm{NH}_{3}$ losses increased with increasing $\mathrm{N}$ doses, respectively 20,28 and $30 \mathrm{~kg} \mathrm{ha}^{-1}$ of $\mathrm{N}$ for 50,100 and $150 \mathrm{~kg} \mathrm{ha}^{-1}$ doses of $\mathrm{N}$. The higher the N-urea dose, the higher the aggregate volatilization $(\mathrm{kg}$ $\mathrm{ha}^{-1}$ of $\mathrm{N}$ ). However, the loss percentage in relation to the total $\mathrm{N}$ per applied dose was $39 \%, 28 \%$ and $20 \%$ respectively for 50,100 and $150 \mathrm{~kg} \mathrm{ha}^{-1}$ doses of $\mathrm{N}$, demonstrating that the percentage ammonia loss decreased over time during the experimental period. Similarly, the higher the $\mathrm{N}$ doses, the higher the loss. However, the percentage of treatments that received higher $\mathrm{N}$ doses showed the lowest losses with respect to the total application. These results show that with high temperatures and low rainfall, losses may vary less among $\mathrm{N}$ applications. These results must be associated to the short experimental period and low rainfall following the implementation of collectors and adverse weather to ureanitrogen fertilization and to the effects of temperature as high as $28.5^{\circ} \mathrm{C}$ (Figure 1). Primavesi et al. (2001) worked with urea in acid soils and observed the $\mathrm{NH}_{3}-\mathrm{N}$ volatilization losses in pastures ranging from $10 \%$ to $25 \%$ of the $\mathrm{N}$ applied during the growth stage.

The best adjustment of the multiple regression for fall was the quadratic form (Figure 4a). It was observed that $\mathrm{N}$ losses were higher in six days after application, which is in agreement with results found by Lara \& Trivelin (1990) and by Martha Junior et al. (2004) and Cantarella et al. (2008).

The canonical analysis of the response surface yielded as stationary point the maximum coordinate point of 6.6 days after application and $132 \mathrm{~kg} \mathrm{ha}^{-1} \mathrm{~N}$ for dose and value at the stationary point of 6.67 (ammonia loss in $\mathrm{kg} \mathrm{ha}^{-1}$ ). 
Rev. Bras. Saúde Prod. Anim., Salvador, v.16, n.1, p.253-264 jan./mar., 2015 http://www.rbspa.ufba.br ISSN 15199940 http://dx.doi.org/10.1590/S1519-99402015000100005

a

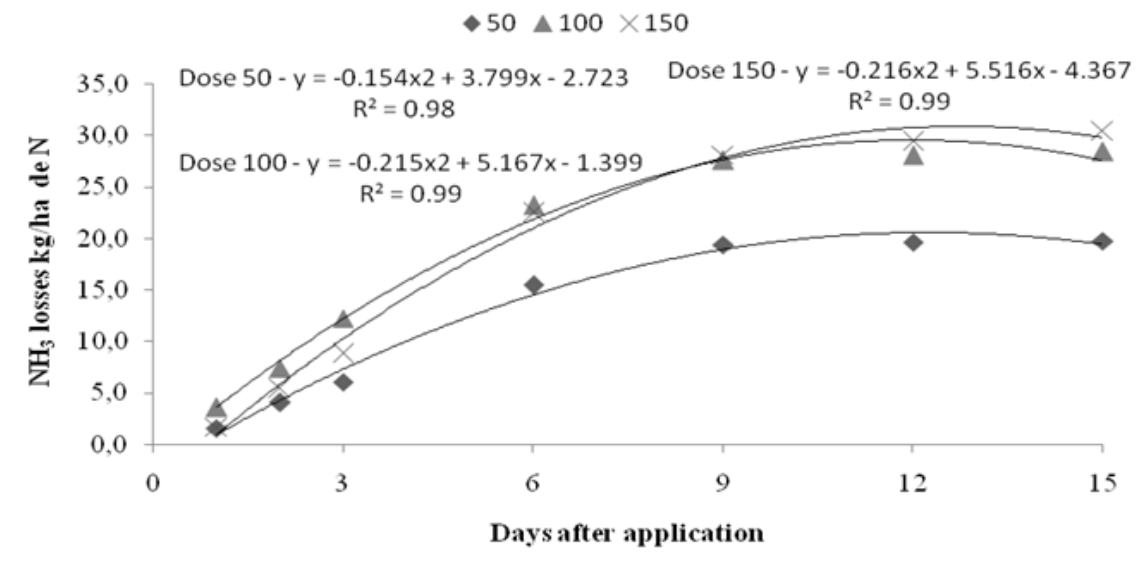

b

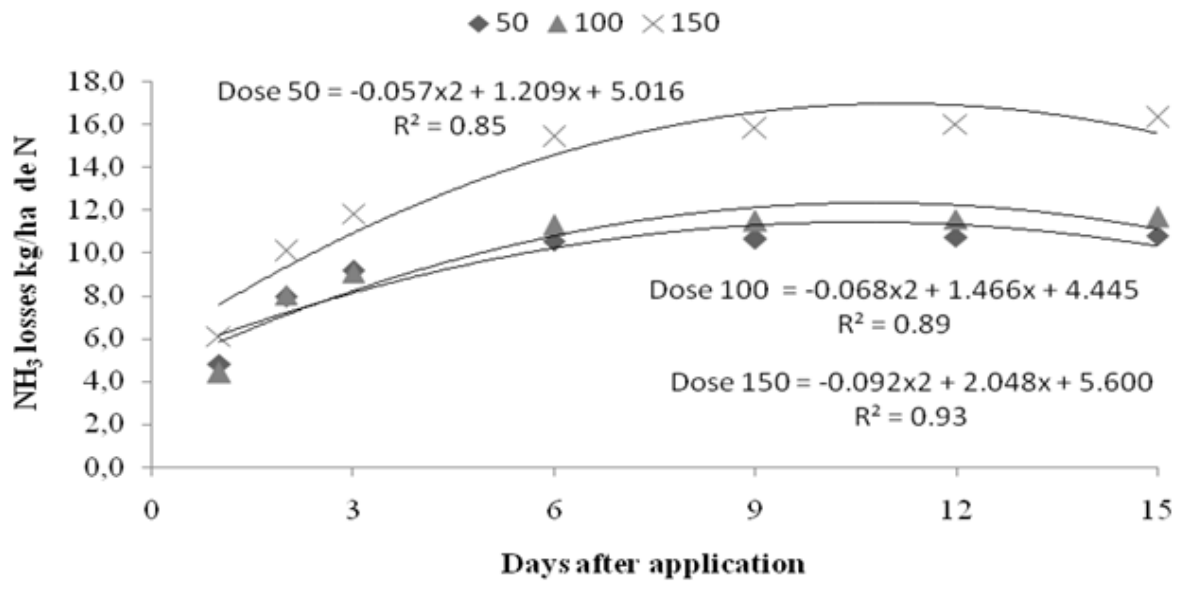

$\mathrm{C}$

$\diamond 50 \triangle 100 \times 150$

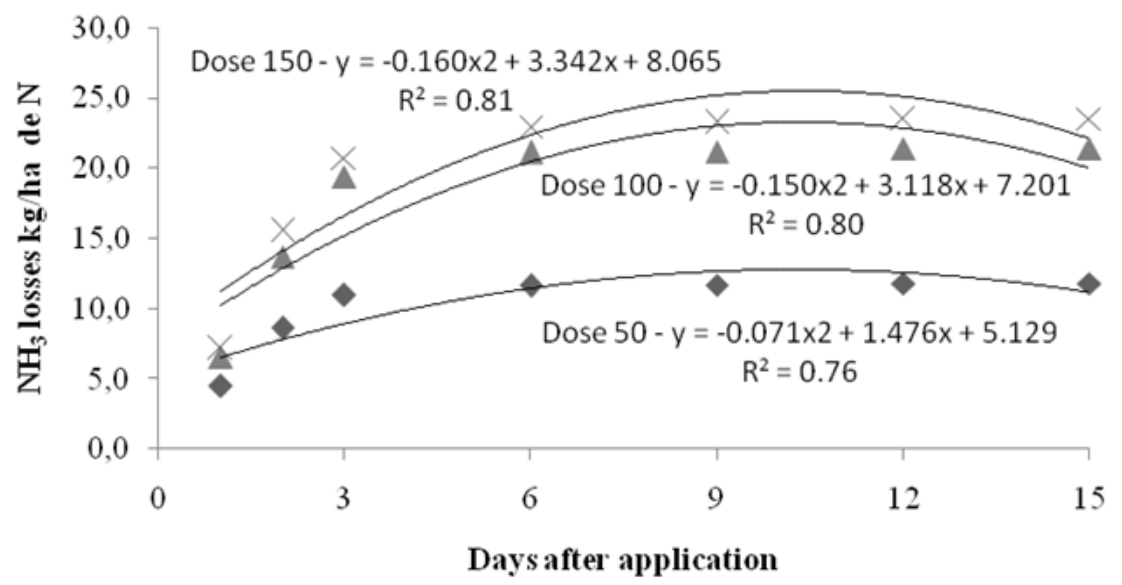

Figure 3. Accumulated $\mathrm{NH}_{3}-\mathrm{N}$ volatilization losses in Tanzania grass pastures fertilizedwith urea levels in fall (a), spring (b) and summer (c) 
Rev. Bras. Saúde Prod. Anim., Salvador, v.16, n.1, p.253-264 jan./mar., 2015 http://www.rbspa.ufba.br ISSN 15199940

a

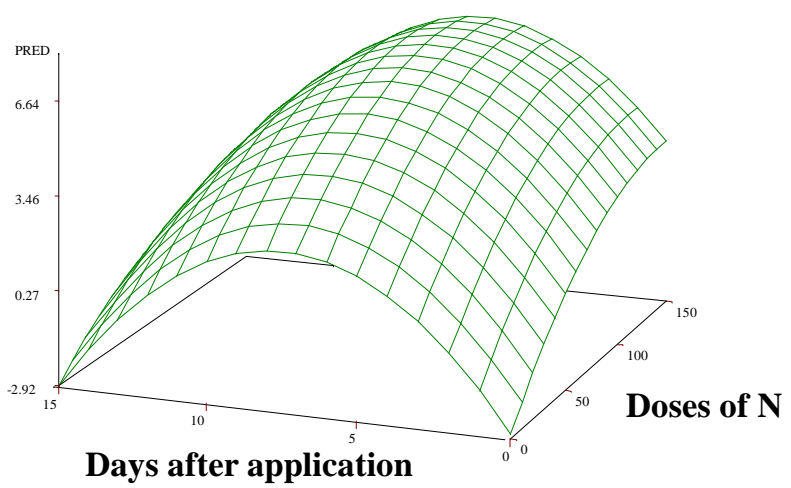

$\mathrm{Y}=-2.76+1.38$ days +0.074 doses $\mathrm{N}-0.093$ days $^{2}-0.0013$ doses $\mathrm{N}$ days -0.00025 doses $\mathrm{N}^{2} \mathrm{R}^{2}=0.52$

b

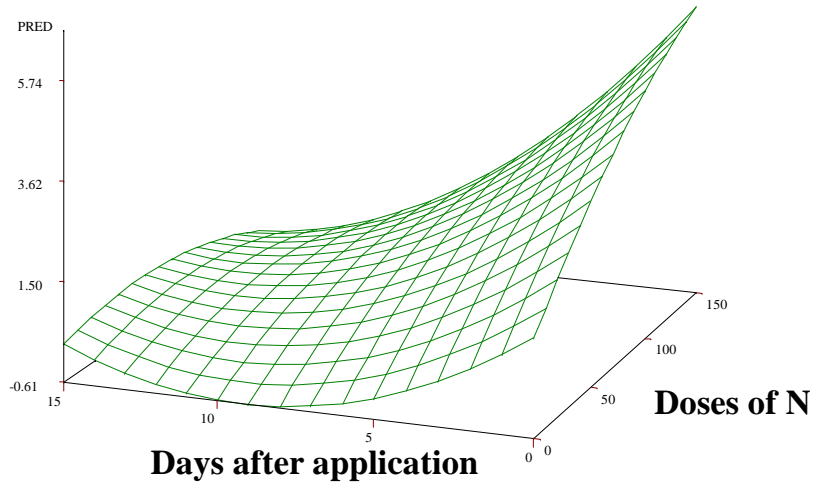

$\mathrm{Y}=1.43-0.446$ days +0.042 doses $\mathrm{N}+0.024$ days $^{2}-0.0021$ doses $\mathrm{N}$ days -0.000087 doses $\mathrm{N}^{2} \mathrm{R}^{2}=0.74$

c

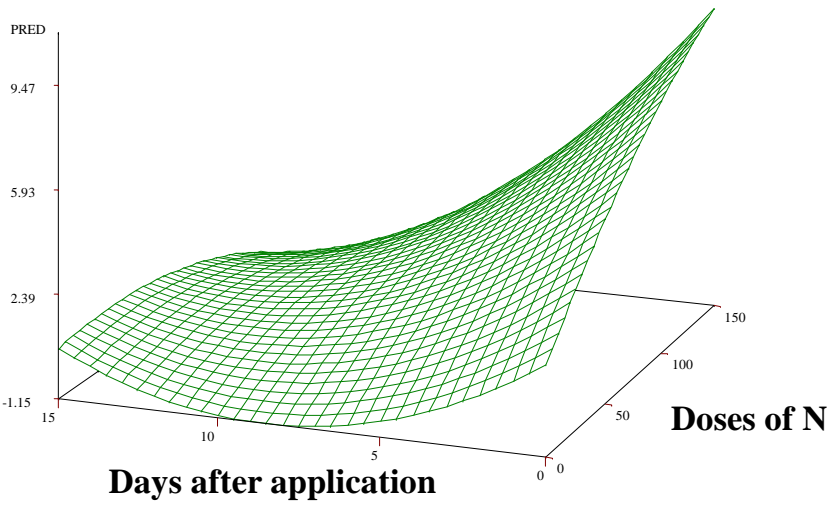

$\mathrm{Y}=1.43-0.446$ days +0.042 doses $\mathrm{N}+0.024$ days $^{2}-0.0021$ doses $\mathrm{N}$ x days -0.000087 doses $\mathrm{N}^{2} \mathrm{R}^{2}=0.74$

Figure 4. Tridimensional response surface for fall (a), spring (b) and summer (c) for days after application as a function of $\mathrm{N}$ doses in Tanzania grass pastures 
$\mathrm{NH}_{3}-\mathrm{N}$ volatilization losses in spring/2007 were significant for the $\mathrm{N}$ urea dose, for the number of days after application and for the interaction between $\mathrm{N}$-urea dose and number of days after application (Figure $3 b$ ).

$\mathrm{NH}_{3}-\mathrm{N}$ volatilization losses were significantly higher for the $150 \mathrm{~kg} \mathrm{ha}^{-1} \mathrm{~N}$ dose. However, the daily $\mathrm{NH}_{3}-\mathrm{N}$ volatilization losses observed demonstrate that the highest loss occurred on the first day, followed by losses on the $2^{\text {nd }}, 3^{\text {rd }}$ and $6^{\text {th }}$ day after application of $\mathrm{N}$ (Figure $2 \mathrm{~b}$ and $3 \mathrm{~b}$ ). These results demonstrate that on the first days of $\mathrm{N}$ fertilization, losses are higher due to the greater volume of $\mathrm{N}$ on the pasture soil but mainly to the weather conditions (MARTHA JUNIOR et al., 2004; CANTARELLA et al., 2008).

Figure $2 \mathrm{~b}$ shows that $78 \%$ of the total $\mathrm{NH}_{3}-\mathrm{N}$ volatilization losses during the experimental period occurred up to the third day after application. On the first three days, the temperature was very high and rainfall of $16.2 \mathrm{~mm}$ occurred on the third day after urea application (Figure 2). This must have contributed to the higher $\mathrm{N}-\mathrm{NH} 3$ loss in that period. These results corroborate those by Martha Junior et al. (2004), who studied urea-fertilized Tanzania grass and found third day aggregate 928sesofrome totan- $\mathrm{NH}_{3}$ losses. From the sixth to the $15^{\text {th }}$ day, the mean $\mathrm{N}$ $\mathrm{NH} 3$ aggregate losses from the $\mathrm{N}$ doses decreased as a fraction of the total loss with respect to the amountof fertilizer applied to the soil, indicating that $\mathrm{N}$ moved from the fertilizer to deeper soil layers.

$\mathrm{N}-\mathrm{NH}_{3}$ aggregate losses increased exponentially with the $\mathrm{N}$-dose applied: $11 ; 12$ and $16 \mathrm{~kg} \mathrm{ha}^{-1}$ of $\mathrm{N}$ for doses of 50,100 and $150 \mathrm{~kg} \mathrm{ha}^{-1}$ of $\mathrm{N}$, respectively, as shown in Figure $3 b$. However, the loss percentage with respect to the total $\mathrm{N}$ per applied dose was $21 \%, 12 \%$ and $11 \%$ for doses of 50 , 100 and $150 \mathrm{~kg} \mathrm{ha}^{-1}$ of $\mathrm{N}$, respectively. Due to the similarity of weather conditions, springtime showed the same ammonia loss pattern as previously discussed for the fall collection. Martha Junior et al. (2004) working with Nfertilized Tanzania grass observed aggregate $\mathrm{N}-\mathrm{NH} 3$ losses of $48 \%, 41 \%$ and $42 \%$ of the $\mathrm{N}$ application for doses of 40,80 and $120 \mathrm{~kg} \mathrm{ha}^{-1}$ of $\mathrm{N}$-urea, respectively.

Primavesi et al. (2006) verified that doses of up to $500 \mathrm{~kg} \mathrm{ha}^{-1}$ of $\mathrm{N}$, in five installments, as urea or ammonia nitrate, did not cause significant nitrate loss to the water table. The results indicate that there is no risk of water table contamination in deep soils of average texture occupied by intensively managed tropical grasses when nitrogen fertilization higher than the forage cycling capacity are not used and when the soil supply potential is taken into account.

The best adjustment of the multiple regressions for spring was the quadratic form (Figure $4 \mathrm{~b}$ ). It is observed that $\mathrm{N}$ losses were higher in the three first days after application in agreement with Lara \& Trivelin (1990), Martha Júnior et al. (2004) and Cantarella et al. (2008). Also, it was observed that in the springtime, losses occurred until the sixth day after application, being then stabilized.

Thus, the stationary point was obtained as saddle point of coordinates with 12.85 days after application and $83 \mathrm{~kg}$ $\mathrm{ha}^{-1}$ of $\mathrm{N}$ for the dose), and the value at the stationary point of 0.31 (ammonia losses in $\mathrm{kg} \mathrm{ha}^{-1}$ ). The saddle point does not have a single maximum or minimum for the graphic model represented because the maximum is a region that is a specific point (stationary point). 
$\mathrm{N}-\mathrm{NH}_{3}$ volatilization losses for summer/2008 were significant for the $\mathrm{N}$-urea dose, for the number of days after application, and for the interaction between $\mathrm{N}$-urea dose and number of days after application (Figure 3c). Daily $\mathrm{N}-\mathrm{NH}_{3}$ volatilization losses demonstrate that the highest losses occurred on the first and second days, followed by the $3^{\text {rd }}$ and $6^{\text {th }}$ days after $\mathrm{N}$ application (Figure 2c). According to Cantarella et al. (1999) and Cantarella et al. (2008), losses are higher on the first days of $\mathrm{N}$ fertilization due to the greater volume of nitrogen on the pasture soil but mainly to the weather conditions. Figure 2c shows that $90 \%$ of $\mathrm{N}^{-\mathrm{NH}_{3}}$ aggregate volatilization losses for the entire experimental period occurred up to de $3^{\text {rd }}$ day after application. The high temperature in the three first days of the experimental period caused a rainfall of $6.6 \mathrm{~mm}$ on the third day after urea application (Figure 3), which may have tod higher $\mathrm{N}^{-\mathrm{NH}_{3}}$ loss in that period. These results corroborate those of previous authors. From the sixth to the $15^{\text {th }}$ days, the mean $\mathrm{N}$ dose as $\mathrm{N}-\mathrm{NH} 3$ aggregate losses decreased as a fraction of the total loss with respect to the amount of fertilizer applied to the soil, indicating that $\mathrm{N}$ moved from the fertilizerto deeper soil layers, improving the likelihood of ion-root contact and better use of the fertilizer by the plant. $\mathrm{N}-\mathrm{NH}_{3}$ aggregate losses increased with the $\mathrm{N}$ dose applied: 12,21 and $24 \mathrm{~kg} \cdot \mathrm{ha}$ 1 of $\mathrm{N}$ for doses of 50, 100 and $150 \mathrm{~kg} \cdot \mathrm{ha}^{-1}$ of $\mathrm{N}$, respectively, as shown in Figure 3c. However, the loss percentage with respect to the total $\mathrm{N}$ per applied dose was $23 \%, 21 \%$ and $16 \%$ for doses of 50,100 and $150 \mathrm{~kg} \cdot \mathrm{ha}$ 1 of N, respectively. Similarly, the higher the $\mathrm{N}$ dose, the higher the loss. However, the percentage of treatments that received higher $\mathrm{N}$ doges showed the lowest losses with respect to the total application. These results indicate that in the three seasons evaluated, ammonia aggregate losses showed the same behavior pattern. Weather conditions at the time of fertilizer application and during the evaluation period, mainly temperature and precipitation may have reflected on the pattern and extent of volatilization losses (WHITEHEAD, 1995).

Evaluating the process of $\mathrm{N}$-urea fertilization efficiency in Brachiaria brizantha-grass associated with application of potassium chloride and simple superphosphate, Oliveira et al. (2003) found that the recovery of $\mathrm{N}$ from $\mathrm{N}$-urea fertilization by the plant crown and the root system was correlated to the dry mass of plant shoots, leading to different forage dry matter yields in plant shoots.

The best adjustment of the multiple regressions for summer was the quadratic form (Figure 4a). It is observed that $\mathrm{N}$ losses were larger in the three first days after application in agreement with Lara \& Trivelin (1990), Martha Junior et al., (2004) and Cantarella et al. (2008).

The canonical analysis of the response surface yielded as stationary point the saddle point with coordinates of 12.33 days after application and $77 \mathrm{~kg} \mathrm{ha}^{-1}$ of $\mathrm{N}$ dose. The value at the stationary point was 0.25 (ammonia loss in $\mathrm{kg} \mathrm{ha}^{-1}$ ). Martha Junior et al. (2004) evaluated the effect of $\mathrm{N}$ doses and reported that for fertilizeramount greater than $80 \mathrm{~kg}$ $\mathrm{ha}^{-1}$ of $\mathrm{N}$, denitrification losses were considerably significant. These authors observed that the combination of high soil humidity, absence of rain on the first day after fertilization and high temperature caused a low agronomic efficiency for $\mathrm{N}$-urea applied on Tanzania grass pasture.

Urea-based pasture fertilization caused higher percentages of $\mathrm{N}$ losses in the three days following application and the 
Rev. Bras. Saúde Prod. Anim., Salvador, v.16, n.1, p.253-264 jan./mar., 2015 http://www.rbspa.ufba.br ISSN 15199940

application of higher $\mathrm{N}$ doses led to the highest aggregate loss. The season of the year influenced the $\mathrm{N}$ loss pattern and volume, and the smallest values were found in springtime, followed by summer and fall. The cumulative $\mathrm{N}-\mathrm{NH}_{3}$ volatilization loss ranged from 78 to $90 \%$ up to the third day after application of the total loss.

\section{REFERENCES}

CANTARELLA, H.; ROSSETO, R.; BARBOSA, W.; PENNA, M. J.; RESENDE, L. C. L. Perdas de nitrogênio por volatilização da amônia e resposta da cana-de-açúcar à adubação nitrogenada, em sistema de colheita de cana sem queima prévia. In: CONGRESSO NACIONAL DA STAB, 7., 1999, Londrina. Anais... Londrina, 1999. p.8287.

CANTARELLA, H.; TRIVELIN, P. C. O.; CONTIN, T. L. M.; DIAS, F. L. F.; ROSSETTO, R.; MARCELINO, R.; COIMBRA, R. B.; QUAGGIO, J. A. Ammonia volatilization from urease inhibitor-treated urea applied to sugarcane trash blankets. Scientia Agricola, v.65, n.4, p.397-401, 2008.

CORRÊA, A. R. Forrageiras: aptidão climática do Estado do Paraná. In: MONTEIRO, A.L.G., MORAES, A., CORRÊA, E.A.S. Forragicultura no Paraná. Londrina: Comissão Paranaense de Avaliação de Forrageiras, 1996. p.1522.

HARGROVE, W. L. Soil environmental and management factors influencing ammonia volatilization under field conditions. In. BOCK, B. R.; KISSEL, D. E. (Eds.). Ammonia volatilization from urea fertilizers. MuscleSchoals: Tenesse Valley Autorithy, 1988. p.17-36.

(Bulletin, Y-206).
KIEHL, J.C. Distribuição e retenção de amônia no solo após a aplicação de ureia. Revista Brasileira de Ciência do Solo, v.13, p.75-80, 1989.

LARA, W.A.R.; TRIVELIN, P.C.O. Eficiência de um coletor semi-aberto estático na quantificação de $\mathrm{N}-\mathrm{NH} 3$ volatilizado da ureia aplicada ao solo. Revista Brasileira de Ciência do Solo, v.14, p.345-352, 1990.

MARTHA JÚNIOR, G.B.; CORSI, M.; TRIVELIN, P.C.O.; VILELA, L.; PINTO, T.L.F.; TEIXEIRA, G.M.; MANZONI, C.S.; BARIONI, L.G. Perda de amônia por volatilização em pastagem de Capim-Tanzânia adubada com ureia no verão. Revista Brasileira de Zootecnia, v.33, n.6, p.2240-2247, 2004.

MARSOLLA, T.; MYAZAWA, M. Determinação espectrofotométrica de amônia volatilizada do solo. In: CONGRESSO LATINO AMERICANO DE LA CIÊNCIA DEL SUELO, 14., 1999, Temuco. Anais... Temuco, 1999. $374 p$.

PRIMAVESI, O.; CORRÊA, L. A.; PRIMAVESI A. C. Adubação com ureia em pastagem de Cynodon dactylon cv. Coastcross sob manejo rotacionado: eficiências e perdas. São Carlos: Embrapa Pecuária Sudeste, 2001. 42 p. (Circular Técnica, 30).

PRIMAVESI, A. C.; PRIMAVESI, O.; CÔRREA, L. A.; CANTARELLA, H.; SILVA, A.G .; FREITAS, A. R.; VIVALDI, L. J. Adubação nitrogenada em capim-Coastcross: efeitos na extração de nutrientes e recuperação aparente do nitrogênio. Revista Brasileira de Zootecnia, v.33, n.1, p.68-78, 2004. 
Rev. Bras. Saúde Prod. Anim., Salvador, v.16, n.1, p.253-264 jan./mar., 2015 http://www.rbspa.ufba.br

PRIMAVESI, O.; PRIMAVESI, A. C.; CORREAA, L. A.; SILVA, A.G .;

CANTARELLA, H. Lixiviação de nitrato em pastagem de coastcross adubada com nitrogênio. Revista Brasileira de Zootecnia, v.35, n.3, p.683-690, 2006.

OLIVEIRA, P. P. A.; TRIVELIN, P. C. O.; OLIVEIRA, W. S. Eficiência da fertilização nitrogenada com ureia $\left({ }^{15} \mathrm{~N}\right)$ em Brachiariabrizantha cv. Marandu associada ao parcelamento de superfosfato simples e cloreto de potássio. Revista Brasileira de Ciência do Solo, v.27, n.4, p.613-620, 2003.

SANTOS, H. G.; JACOMINE, P. K.T.; ANJOS, L. H. C. (Eds.). Sistema brasileiro de classificação de solos. 2 . ed. Rio de Janeiro: Embrapa Solos, 2006. p.306.

STATISTICALANALYSIS SYSTEM INSTITUTE. SAS/STAT Procedure guide personal computers. 9. ed.Cary, NC. Inst, 1999. 334p.

SENGIK, E.; KIEHL, J. C. Controle da volatilização de amônia em terra tratada com ureia e turfa pelo emprego de sais inorgânicos. Revista Brasileira de

Ciência do Solo, v.19, p.455-461, 1995.

WERNER, J. C.; PAULINO, V. T.;

CANTARELLA, H.; ANDRADE, N.de O.; QUAGGIO, J. A. Forrageiras. In: Recomendações de adubação e calagem para o Estado de São Paulo. 2 ed. Campinas: Instituto Agronômico e Fundação IAC, 1996. p.263-273. (Boletim técnico, 100).

WHITEHEAD, D. C. Grassland nitrogen. Wallingford: $\mathrm{CAB}$ International, 1990. 397p.

Data de recebimento: 10/04/2014

Data de aprovação: 25/02/2015 